\title{
Budapesti kerékpárutak allergén pollenterhelése
}

\section{Allergenic potential of tree lines along cycle tracks in Budapest}

Szerzők:

\author{
Mányoki Gergely, Udvardy Orsolya, Kajtor-Apatini Dóra, Orlóci László, Magyar Donát $\bowtie$ \\ a: Nemzeti Népegészségügyi Központ, Budapest, b: Eötvös Loránd Tudományegyetem \\ Botanikus kertje (Füvészkert), Budapest
}

Beküldve: 2019. 05. 29.

doi: $\quad$ 10.24365/ef.v60i4.477

\begin{abstract}
Összefoglaló:
Bevezetés: Az allergia hazánkban már népbetegség. A megelőzés egyik legfőbb eszköze a polleninformáció. Az egyes városi zöldterületek allergénterhelésének becslése modellszámítás segítségével végezhető, melyet ezidáig csak városi parkok esetén végeztek. Jelen dolgozat célja az allergénpollen-adó fák elegyarányának felmérése, és egy modellezési módszer kipróbálása a budapesti kerékpárutakat szegélyező fasorok allergénterhelésének becslésére.
\end{abstract}

Módszertan: A modellben a növényzet kiterjedését és összetételét súlyoztuk a szakirodalomban közölt allergenitásuk szerint. A vizsgálat során tíz budapesti kerékpárút fakataszteri adatait használtuk fel.

Eredmények: A megvizsgált kerékpárúti fasorok összesen 2355 faegyede mintegy 60 taxonba (faj, fajta és változat) sorolható be. Ezek közül 10 taxon (17\%) tekinthető erősen allergénnek. Nagyobb arányban előforduló allergén taxonok a kőrisek, a platánok és a zöld juhar, míg a nyír-, éger-, füz- és tölgyfajok csak színező elemként jelennek meg. A fák fele tartozik erősen allergén taxonba, ez 1175 db példányt jelent. Közepes allergenitással a fák 31\%-a bír (732 db). Következtetések: A modell nem bizonyult megbízhatónak a fasorok jellemzésére, mivel a számításhoz szükséges területkijelölés sok esetben nem egyértelmű. A fasorok allergénterhelésének kifejezésére az allergén egyedek elegyarányán alapuló módszert javasoljuk. Jelen eredményeink alapján fontosnak tartjuk a kerékpárutak további fásítása során az allergológiai szempontok figyelembevételét.

Kulcsszavak: városi zöldterületek; városi kerékpározás; pollen; allergia; fasorok

\section{Summary:}

Introduction: Seasonal allergic rhinitis is a common disease in Hungary and has been considered a national affliction. Pollen information is proved to be an useful tool in the prevention of allergy. Urban green areas could act as a source of allergenic pollen grains. Their burden of allergy caused by green areas could be estimated with mathematical models. Previously models have been applied only on urban parks but not tree lines. The aim of this study is to calculate the proportion of allergenic trees and a model to express allergenic potential of tree lines planted along cycle tracks in Budapest, Hungary.

Methods: In the model, the area and composition of tree species of the tree lines are weighted with their allergenicity given by the medical literature.

Results: Data of ten tree inventories were used in this study, with a total of 2355 trees belonging to 60 taxa (species and varieties). Amongst them, 10 taxa (17\%) could be considered as highly allergenic. Common allergenic tree taxa found in the tree lines are: ash, plane and box elder, while birch, alder, willow and oak species appeared only as sporadic elements. The half 
of the trees (1175 individual trees) blonged to highly allergenic taxa. 31\% of the trees (732) belonged to taxa known as moderate allergen.

Conclusions: The model is not recommended in the allergological evaluation of tree lines, because the area definition contains uncertainty but it is suggested to calculate the proportion of allergenic trees in tree lines. Our results draw attention to the need of considering the health effects of tree composition along cycle tracks during future planning of green areas.

Keywords: urban green areas; urban cycling; pollen; allerg; tree lines

\section{BEVEZETÉS}

A világszerte egyre növekvő betegségterhet jelentö ${ }^{1}$ allergia Magyarországon mára népbetegséggé vált. Az allergiás megbetegedések megelőzésének, primér prevenciójának egyik legfőbb eszköze a polleninformáció ${ }^{2,3}$, amelynek alapja a folyamatos levegőminta-vételezés és pollenkoncentráció-mérés. A levegőminták gyűjtését háztetőkön, 10-20 méteres magasságban (a fák lombkorona szintje felett) elhelyezett ún. Hirst- típusú (Burkard) pollencsapdákkal végzik. ${ }^{4,5,6}$ Ennek oka, hogy az így kapott pollenszám egy nagyobb térségre vonatkoztatott átlagos, irányadó érték (kb. 50 km-es sugarú kör). Azonban a légzési magasságban (1,5 m) mért koncentráció a térségre megadott átlag többszöröse is lehet egy adott növényfaj esetében; főként a pollenforrás közvetlen szomszédságában, így a zöldfelületek (pl. gyomos ruderáliák), illetve városi zöldterületek (pl. telepített fasorok, parkok, kertek) közelében. ${ }^{7}$ Bár a pollencsapdák ilyen lokális pollenforrások mérésére is használhatók, 8,9,10,11,12 azonban alkalmazhatóságuk itt erősen korlátozott. A talajfelszín közelében ugyanis a levegő kisebb mértékben keveredik át, a pollenszemek nem oszlanak el egyenletesen, előfordulhatnak kis méretű, nagy sűrüségű pollenfelhők. ${ }^{13}$ Emiatt a pollenösszetétel és a légköri koncentráció nagyon változó, és nem a nagyobb térségre vonatkozó átlagot képviseli. Magától értetődő az is, hogy nem lehet minden parkban és kertben pollencsapdát múködtetni. A lokális pollenadó források allergénterhelését azonban modellszámítások segítségével is elvégezhetjük. ${ }^{14,15}$ Az ilyen modellekben a növényzet kiterjedését és összetételét súlyozzuk allergenitásuk szerint, figyelembe véve a zöldfelület egyes alkotóelemeinek (faegyedek, sövények, gyepfelület) releváns tulajdonságait. E tulajdonságok egyaránt lehetnek mérési, becslési, átlagra kifejezett vagy tapasztalati úton jellemzőnek vett értékek (pl. a törzs vagy korona dendrometriai adatai).

A zöldterületek allergénterhelésének becslését ezidáig csak parkok esetén végezték. ${ }^{14,15,16,17}$ Azonban az utcai fasorok allergénterhelése is fontos kérdés, főleg, ha azok városi futó- és kerékpárutak mentén találhatóak. A kerékpározás kedvező egészségi és környezeti hatásai ma már jó ismertek. ${ }^{18,19} \mathrm{~A}$ városi kerékpárutakat szegélyező zöldterületek jelentős szerepet töltenek be a kerékpárosok egészségvédelmében a pormegkötő ${ }^{20,21}$ és árnyékoló hatásuk révén22, de esztétikai értékük sem elhanyagolható szempont, mivel motiválják a kerékpározókat. ${ }^{23}$ Ugyanakkor felmerül annak a lehetősége, hogy allergénpollen-adó fákkal szegélyezett kerékpárutakon a sportolók nagyobb menynyiségú allergénnek lehetnek kitéve. Jelen dolgozat célja a budapesti kerékpárutakat szegélyező allergénpollen-adó fák felmérése, a zöldterületek allergénterhelésének megállapítása, valamint modellezési módszer kipróbálása a budapesti kerékpárutakat szegélyező fasorok allergénterhelésének becslésére.

\section{MÓDSZERTAN}

A vizsgálatokhoz tíz jelentősebb forgalmú budapesti kerékpárút fakataszteradatait használtuk fel, amelyet a FŐKERT Nonprofit Zrt. bocsátott a rendelkezésünkre. A területválasztás a vizsgálat tárgyától független szempontok alapján történt meg, így például a kerékpárút menti gépjármúforgalom (előzetesen mért levegőszennyezettség, Vaskövi és mtsai, ${ }^{24}$ valamint Péter és mtsaii ${ }^{25}$ alapján), továbbá a kerékpárforgalom figyelembevételével (Budapest 2016-os önkéntes alapú Heatmap felmérés térképe, ${ }^{26}$ [1. ábra]). Mintaterületeink: Andrássy út, Bem rakpart, Esze Tamás utca, Kós Károly sétány, 
Könyves Kálmán körút, Nánási út, Olof Palme sétány, Szentendrei út, Szilágyi Erzsébet fasor, Vajdahunyad vára kerékpárút.

Az áttekintést adó fajelegyarány-vizsgálathoz valamennyi, fent felsorolt terület faegyedére (törzs) vonatkozó adat felhasználásra került. A taxonok allergenitását az alábbi szakirodalmak figyelembevételével soroltuk be a megfelelő allergenitási fokozatba: ${ }^{14,15,27-38}$

A modellszámítások során Cariñanos és munkatársai ${ }^{14,39}$ által kidolgozott Urban Green Zone Allergenicity Index („Városi Zöld Zóna Allergenitási Mutató”, a továbbiakban lugza -modell, [2. ábra]) alkalmazhatóságát vizsgáltuk meg budapesti kerékpárutakat szegélyező fasorok esetén. A modellt eredetileg a városi parkok értékelésére fejlesztették ki. Segítségével adott területre kifejezhető az allergénterhelés (összesített allergizáló hatás). Az index fontos eleme az ún. potenciális allergenitás (potential allergenicity value) amelyet a fajra jellemző tulajdonságokból képez $\left(a p_{i}, p_{i}\right.$ és $\left.p p p_{i}\right)$, majd pedig figyelembe veszi az adott területen előforduló egyedek méretét $\left(H_{i}, S_{i}\right)$. A modell ezt az értéket viszonyítja a vizsgált terület teljes területének $\left(\mathrm{S}_{\mathrm{T}}\right)$ lehetséges legmagasabb allergénterheléséhez (378).

1. ábra: Budapest útjainak kerékpáros-forgalma (úthasználat-intenzitás, 2016) a Heatmap szerint26

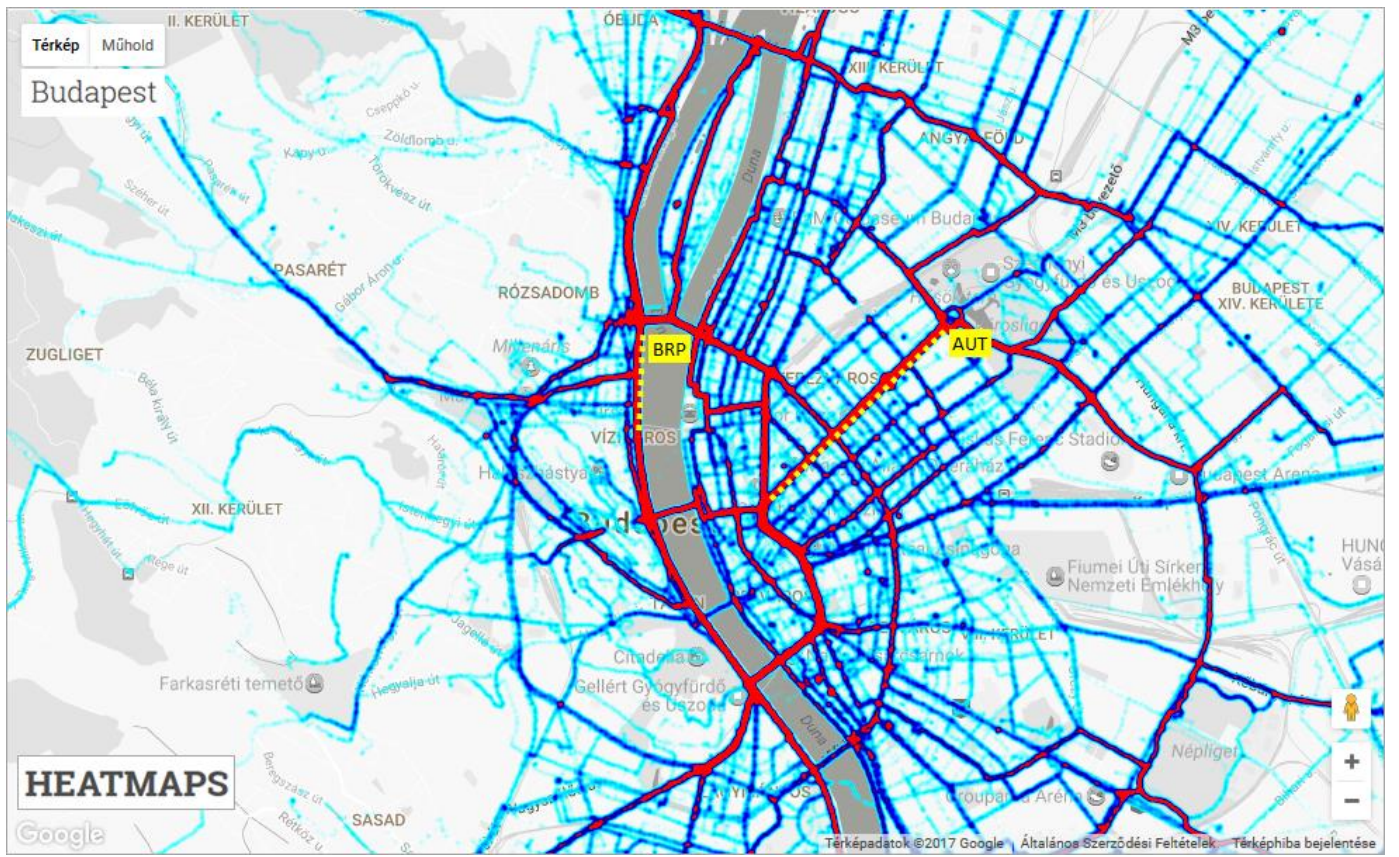

2. ábra: A IUGZA modell (Urban Green Zone Allergenicity Index, „Városi Zöld Zóna Allergenitási Mutató”) Cariñanos és munkatársai14 alapján

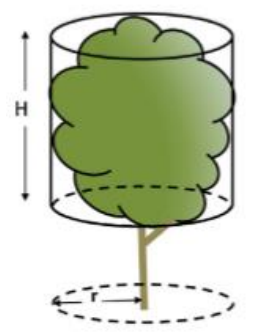

$$
I_{\mathrm{UGZA}}=\frac{1}{378 S_{\mathrm{T}}} \sum_{i=1}^{k} n_{i} \times \mathrm{ap}_{i} \times \mathrm{pe}_{i} \times \mathrm{ppp}_{i} \times S_{i} \times H_{i}
$$


ahol:

k = a fajok száma;

$\mathrm{n}_{\mathrm{i}}=$ a fajokhoz tartozó egyedek száma;

$a p_{i}=i$-fajok allergenitási foka (a vonatkozó szakirodalom alapján a felvehető érték: 0, 1, 2, 3, vagy kivételes esetben 4, ahol 4 a legerősebb allergenitást jelöli);

pe $_{\mathbf{i}}=$ az i-fajok pollenkibocsátás kategóriája megporzástípus alapján (felvehető érték: 0, 1, 2 vagy 3, ahol 0: kétlaki növények női egyedei, 1: rovarbeporzású növények, 2: vegyes, azaz rovar- és/vagy szélbeporzású növények, 3: szélbeporzású növények);

$\mathrm{ppp}_{\mathrm{i}}=$ az i-fajok virágzási időtartama (felvehető érték: 1,2 vagy 3, úgymint 1-3, 4-6 és $\geq 6$ hét);

$\mathrm{H}_{\mathrm{i}}=$ a faegyedek lombkorona-magassága $(\mathrm{m})$ (az ajánlás szerint ez kategóriákban is megadható: 2, 6, 10 és 14 (18) méter). Gyepnövényzet és a cserjék esetén is megadható a méret;

$\mathrm{S}_{\mathrm{i}}=$ az egyedek felszínborítása, a fáknál lombkorona-vetület, $\mathrm{r}^{2} \times \pi\left(\mathrm{m}^{2}\right)$;

$\mathrm{ST}=$ a vizsgált zöldterület ( $\mathrm{pl}$. park) teljes területe $\left(\mathrm{m}^{2}\right)$;

$378=a z a p_{i} \times p e_{i} \times p p p_{i} \times H_{i}$ szorzat maximális értéke $(H=14)$.

Az index tehát egy létező vagy tervezett városi zöldterület allergénterhelését mutatja, összehasonlítva azt egy hasonló adottságokkal, de maximális allergénterheléssel bíró hipotetikus területtel. Az eredeti módszerhez képest pontosítottunk a modellszámítás módján: méretkategóriák helyett valós, mért famagasság adatokat használtunk. A fakataszterben szereplő adatok közül ezen túl a fafaj, a törzspozíció és a lombkorona-átmérő adatokat is figyelembe vettük. A lugza modell szerinti hányados értéke 0 és 1 között helyezkedhet el, ahol a 0 a "nem allergizáló" területet jelenti, míg az 1 a legmagasabb allergénterhelést. A szerzők iránymutatása szerint a 0,5 körüli érték már „erősen allergizáló”-nak tekintendő, a 0,15 pedig alacsony allergénterhelést jelent.

A modellszámításhoz kizárólag olyan fasorokat vontunk be a vizsgálatba, amelyeknek közvetlen szomszédságban nem található parkos, fás környezet. Ez esetben ugyanis a terület lehatárolása (a két zöld terület elválasztása) nem végezhető el egyértelmű szempontok szerint, és ezért jelentős eltérések adódhatnak az eredményben. Például az Olof Palme sétányt szegélyező fasor ilyen okból kiesett a vizsgálati körből, hasonlóképpen az Esze Tamás út kertvárosi környezete és a Könyves Kálmán körút egyes szakaszai. Végül három kerékpárutat választottunk ki a vizsgálatra: a Nánási út, az Andrássy út és a Bem rakpart.

Az lugza modellhez szükséges területszámításhoz a kerékpárutakat további útszakaszhatárokra (kereszteződések által lehatárolt egységekre) bontottuk, és megmértük ezek hosszát, majd egységesen 22 méteres szélességet jelöltünk ki az átlagos útszélesség alapján. [3. ábra]

3. ábra: Példa a modellszámítás alapjául szolgáló területkijelölésre az Andrássy úti kerékpárút menti fasornál (fehérrel keretezve). Szakaszhatár: Káldy Gyula u. - Dalszínház u. Forrás: Google Térkép/Google Earth 2019

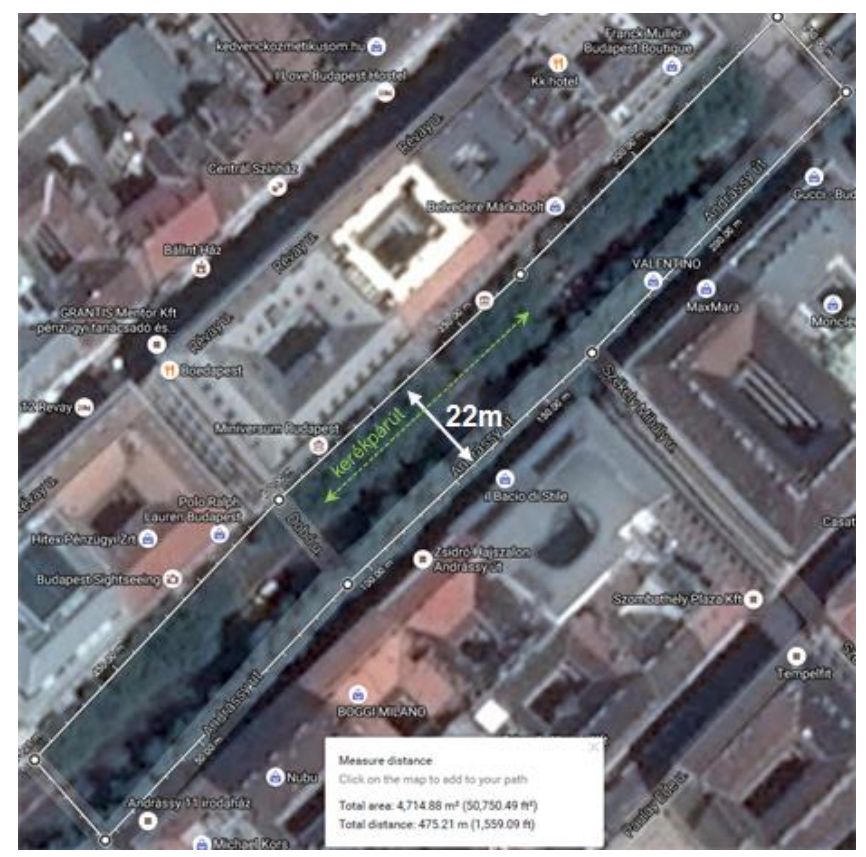




\section{EREDMÉNYEK}

A tíz megvizsgált kerékpárúti fasor összesen 2355 faegyede mintegy 60 taxonba (faj, fajta és változat) sorolható be. Ezek közül 10 taxon tekinthető erősen allergénnek (17\%), amelyek közül az alábbiak emelendőek ki: a kőrisek, a platán és a zöld juhar. A nyír-, éger, füz- és tölgyfajok csak színező elemként jelennek meg. A fajok 32\%-a (19 faj) közepesen allergén; az enyhén vagy alig allergének a fajok $51 \%$ át adják.
$\mathrm{Az}$ egyedek számát tekintve a helyzet némileg kedvezőtlenebb képet mutat: a fák fele tartozik erősen allergén taxonba, ez 1175 db példányt jelent. Közepes allergenitással a fák 31\%-a bír (732 db). Enyhén, vagy alig allergén fák csak az esetek 19\%ában fordultak elő (448 db) a vizsgált fasorokban. [4. ábra]

A három, modellszámításba bevont kerékpárút átlagos allergenitási értéke a lugza modell szerint: Nánási út: 0,20; Andrássy út: 0,10; Bem rakpart: 0,03. [5. ábra]

4. ábra: Allergenitási fokok szerinti összesitett megoszlás a fafajok és faegyedek alapján az összes vizsgált, budapesti kerékpárút mentén

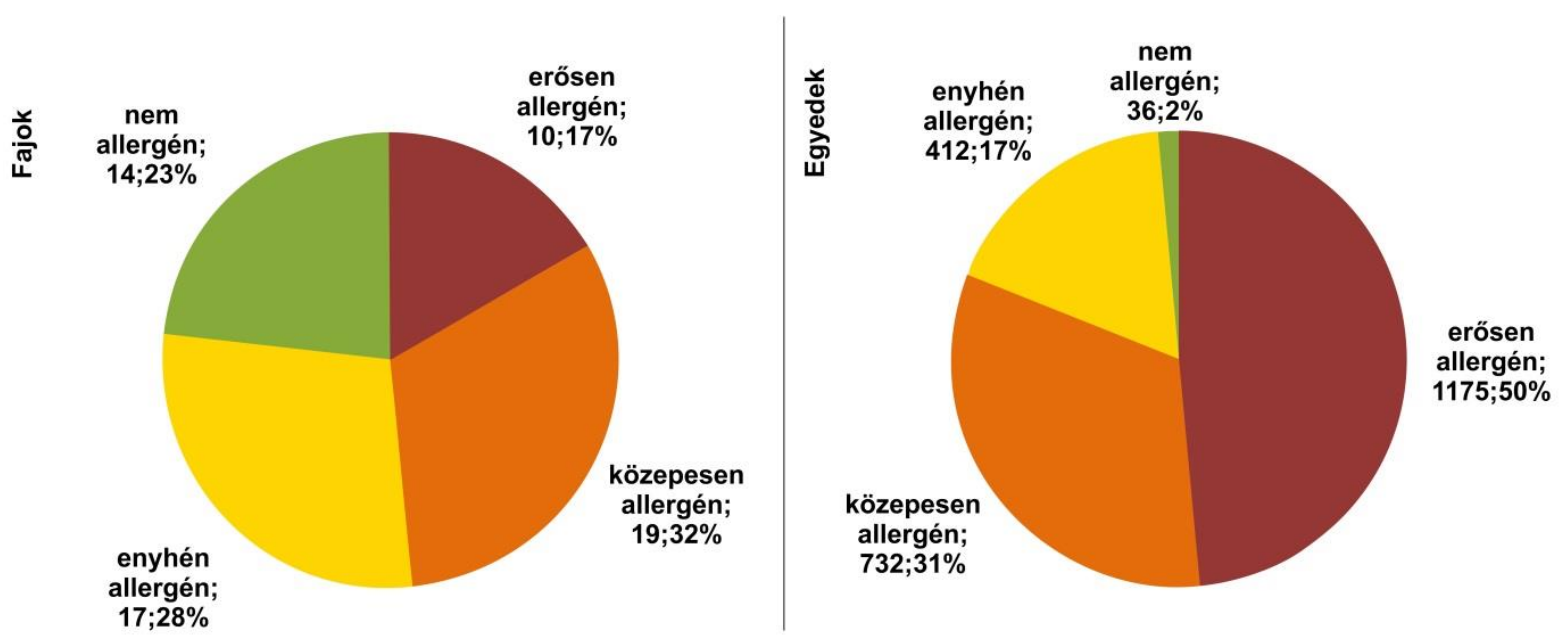

5. ábra: A budapesti kerékpárutak mentén húzódó fasorokra meghatározott allergénterhelés átlagértékei a módositott IUGZA modell szerint. Kiemelt összallergenitás értékhatárok: 0,15: alacsony szintü allergénhatás, 0,5: erősen allergizáló

0,5

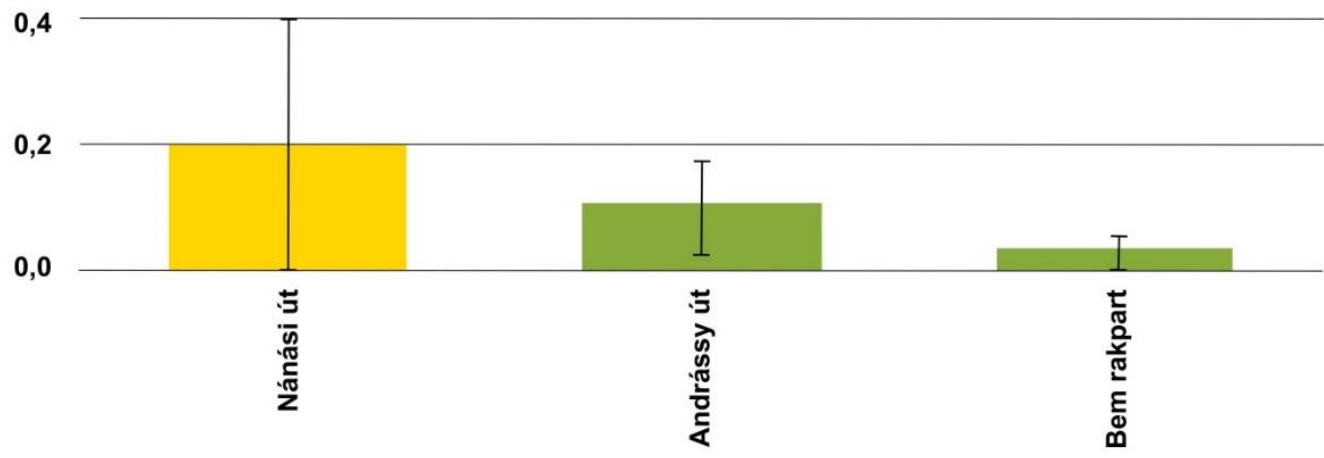


E három fasor az alábbiak szerint jellemezhető:

- Nánási út: több ízben magas, 15-20 méteres, igen diverz fajösszetételú, vegyes elegyarányt és megjelenést mutató sorfák, pl. a magas allergenitású platánok (Platanus), vagy a közepesen allergén nyárfákkal (Populus) és juharokkal (Acer). A fasor kertvárosi környezetben található.

- Andrássy út: átlagosan 9 m magas, még fiatal, magas allergenitású kőrissel (Fraxinus) és közepesen allergén ostorfával (Celtis). Belvárosi környezetben önálló zöldterületet képvisel.

- Bem rakpart: átlagosan kb. 9 m magas fasor, amelynek fő alkotóeleme az alacsony allergenitású, jó várostűréssel bíró, rovarbeporzású japánakác (Sophora). A Duna közelsége miatt jól átszellőzött terület.
Az elegyarányokat az 6. ábra-n láthatjuk, az allergenitási fokok színek szerinti jelölésével. A 7. ábra-n az allergenitási fokok szerinti megoszlások láthatók. Az erősen allergén faegyedek száma az összes faegyed vonatkozásában az Andrássy úton, a Könyves Kálmán körúton és a Szentendrei úton viszonylag magas. Megállapítható ugyanakkor, hogy a fasorok többségében a közepesen allergén fajok dominálnak. Az Andrássy úton a fajok száma (diverzitás) is alacsony, mindössze 4 faj van jelen. A legalacsonyabb fajszám a Kós Károly sétányon adódott (2 faj), azonban a környező Városliget fajgazdagsága ezt ellensúlyozza. A legtöbb fajt felvonultató fasor a Szentendrei út, ahol mintegy 30 különböző faj található a kerékpárút mentén.

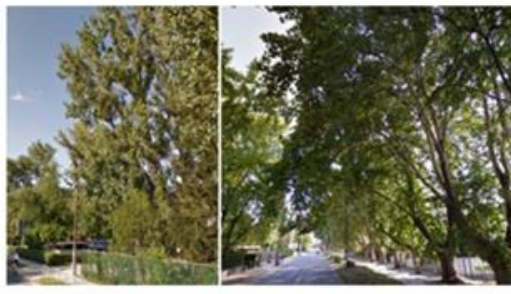

NÁNÁSI ÚT platánnal, juharral és nyárfával
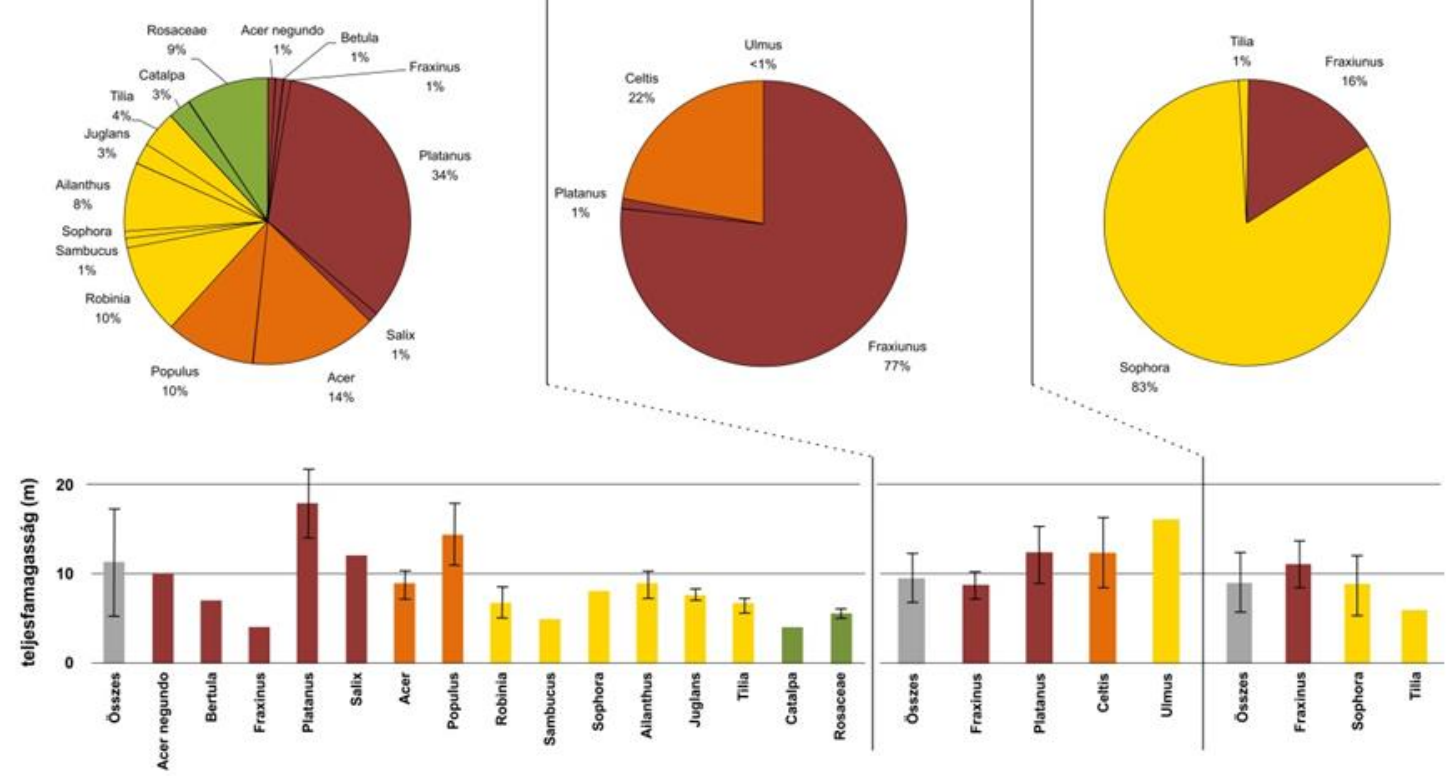
7. ábra: Allergenitási fokok szerinti megoszlások (a,b,d); az allergenitás szerinti csoportok előfordulása (c) (egyedszám) budapesti kerékpárutakon

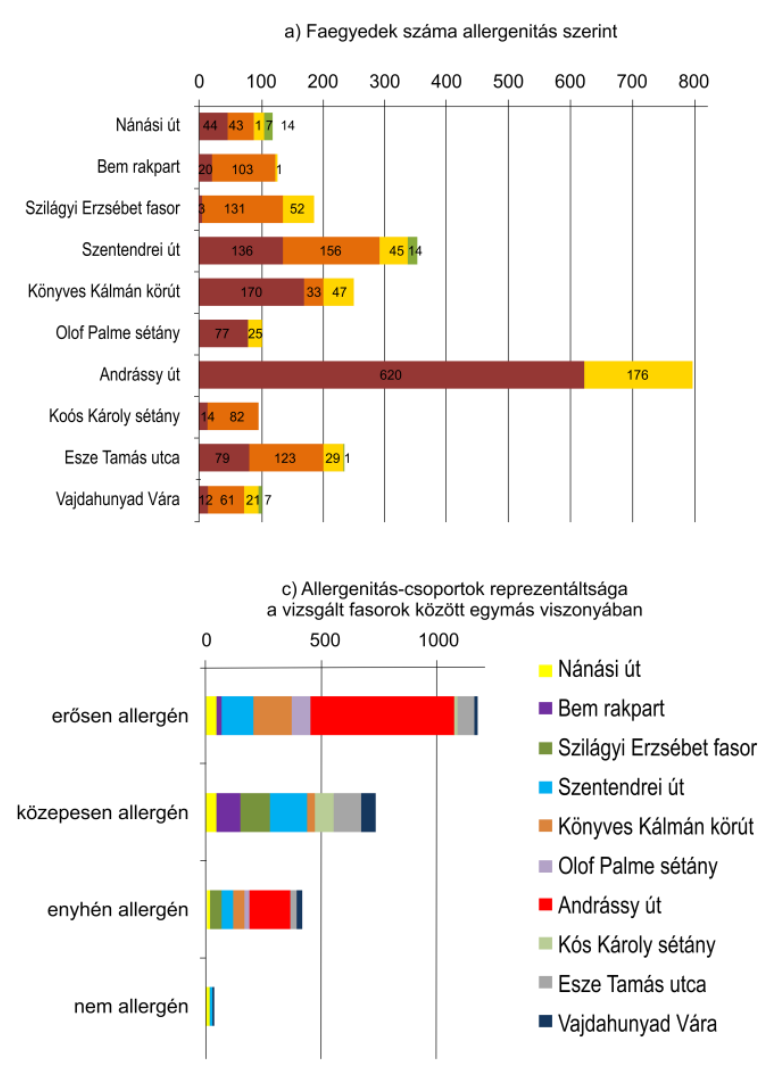

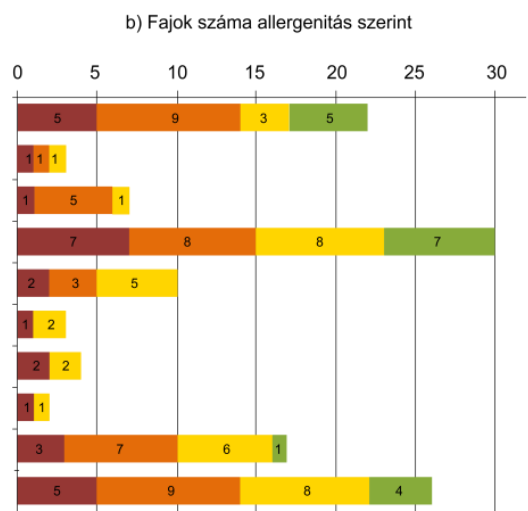

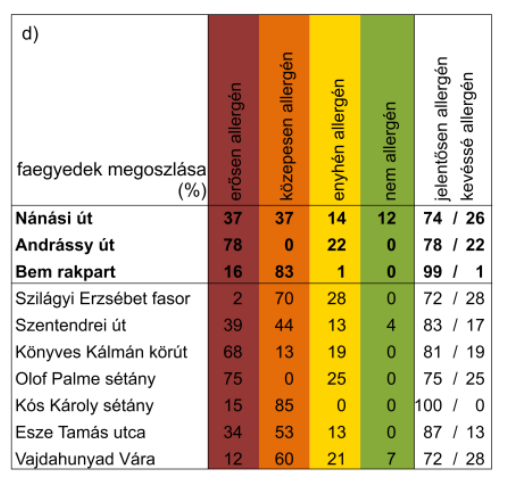

\section{MEGBESZÉLÉS}

A városi lakosságot érő allergén-expozíció csökkentése fontos feladat, amelynek alapja az allergén pollenadó források ismerete és meghatározása. Magas kockázati csoportnak tekinthetők a városi kerékpárúthasználók. A kerékpárosok mozgás közben fokozott légcserét végeznek, így a szervezetükbe jutó allergénmennyiség is nagyobb. ${ }^{40} \mathrm{Az}$ allergénhatást tovább fokozza, ha ezeket a helyszíneket forgalmas utak mentén alakítják ki, ahol a pollenszemek allergenitását a kémiai légszennyező anyagok növelik. ${ }^{41-44} \mathrm{~A}$ városi kerékpárutak mentén található fasorok allergénterhelésének megállapítására korábban nem volt kísérlet. A kerékpárutak allergénterhelését az utat szegélyező allergén fafajok elegyaránya és a lugza modell alapján vizsgáltuk.

Az allergén fafajok elegyarányában jelentős eltérés van az egyes kerékpárutak között, így ebből adódóan az allergénterhelésben is nagy különbségek lehetnek. A Bem rakparton 16, míg az Andrássy úton $77 \%$ az allergén fajok aránya, amelyben túlnyomórészt kőrisek szerepelnek. Ezt a kőrisallergiásoknak mindenképpen érdemes számításba venni a pollenszezonban, amikor is javasolt az Andrássy út helyett más közlekedési útvonalat választani. A fajszámot elemezve látható, hogy egyes fasorokban nagyon alacsony a biodiverzitás, $s$ amennyiben az allergén egyedek szerepelnek többségben, az ilyen utakon az allergénterhelés jelentőssé válik. Az alacsony biodiverzitás sok esetben a fasor védett, városképi jellegének fenntartásából következik. A nagyobb pollenkibocsátáson túl ezeknél a homogén állományoknál fokozottabban jelentkezik a növényvédelmi járványok kockázata is. Mégis e kedvezőtlen hatásokkal szemben a városkép megőrzésének szempontja nagyobb súllyal esik a latba, ezért e fasoroknál továbbra sem számíthatunk az 
allergén fajok fokozatos cseréjére. Fontos kiemelnünk, hogy az allergén fajok számával szemben kifejezőbb az allergén egyedek aránya, mivel ezzel fejezhető ki a pollenadó fák mint pontforrások mennyisége. Itt azonban fel kell hívnunk a figyelmet arra, hogy az egyes növények potenciális allergenitásának megállapítása és kategóriába sorolása sok esetben nem egyértelmú a szakirodalomban fellelhető ellentmondások miatt. Ez abból ered, hogy az egyes szerzők más-más szempontokat vettek figyelembe az értékelés során. A jövőben az allergenitást pontos definíciók alapján kell kategóriákba sorolni. A lugza modell a számításokban szereplő három kerékpárút egyikén sem jelzett magas szintű allergénterhelést. Figyelmet érdemel, hogy a Nánási út lugza modell szerinti allergénterhelése kétszer nagyobb, mint az Andrássy úté. A két említett út különbsége annak köszönhető, hogy a Nánási út idős, nagy lombkorona-magasságú fákkal szegélyezett, míg az Andrássy úton fiatal, kis méretû fák találhatók (4. ábra). A lugza modell számításba veszi a fák méretét is, ezért az allergénterhelés magasabb értéket mutat a Nánási úton, jóllehet az Andrássy úton több az allergén faegyed. Azonban a modell a tízből csupán három kerékpárút esetében volt használható. Nem alkalmazható a modell például a Szentendrei út esetében, ahol pedig az erősen allergén zöld juharral találkozhatunk nagy mennyiségben.

A lugza modell felhasználását az korlátozza, hogy csak a jól körülhatárolt, önálló zöldfelületek esetén alkalmazható, amelyeknek közvetlen szomszédságában nem található parkos, fás környezet, mivel ez bizonytalanná teszi a terület határának pontos kijelölését, és nagyban befolyásolja az erre épülő további számításokat. A kritériumnak tehát csak a kerékpárutak kis része felel meg. További vizsgálatok szükségesek a modell átalakítására annak érdekében, hogy az a többi kerékpárútra, illetve egyéb, fasorral szegélyezett, vonalas létesítményre is kiterjeszthető legyen. A faegyedek egyes minőségi jegyei (pl. növény-egészségügyi állapotjelzők, légszűrő képesség) szintén fontos szerepet játszhatnak az összallergenitás kialakulásában, de jelenleg ezekre nem terjed ki a modell - a későbbiekben ezeket szintén érdemes lenne figyelembe venni. A fentiek alapján tehát az eredetileg parkok felmérésére kidolgozott lugza -modell kevésbé túnik megbízhatónak a sorfák allergén terhelésének becslésére. A továbbiakban az allergén egyedek elegyarányán alapuló értékelést javasoljuk.

A várostervezés növényzet-telepítési gyakorlatában sokáig a gazdasági és kertészeti szempontok voltak a meghatározóak (pl. várostűrő képesség). Azonban napjainkban az allergiás megbetegedések tömegessé váltak, ezért a zöldfelület-gazdálkodási szempontok között a növényzet pollenadó képessége is megjelent. $E$ területen kertészeti és egészségügyi szakemberek együttmúködése kulcsfontosságú. A zöldfelületek allergenitására vonatkozó eredmények megfelelő kommunikációjára is ki kell térnünk. A növényzet allergológiai felmérésének nem célja a fák kivágatása, ezért el kell kerülni minden olyan félreérthető kijelentést, ami esetleg ehhez vezetne. Cél az egészségtudatos zöldfelület-tervezés kialakítása, és azon nemesített növényfajták, változatok előtérbe helyezése, amelyek az alapfajhoz képest jelentősen kevesebb pollent bocsátanak ki. ${ }^{45,46}$ E szempontok figyelembevételével ajánlások készíthetők, amelyek tartalmazzák, mely fafajok, illetve fajták telepítése javasolt, és melyeké kerülendő. ${ }^{17,39,47-49}$ Jelentős szerepet töltene be az allergiások betegségterhének csökkentésében, ha a közegészségügyi szempontok bekerülnének a zöldfelület-gazdálkodási tervek szempontjai közé. Az első lépést ebbe az irányba a városi zöldterületek allergén-terhelésének elemzése jelenti.

\section{KÖSZÖNETNYILVÁNÍTÁS}

A szerzők köszönetüket fejezik ki a FŐKERT Nonprofit Zrt.-nek, hogy a fakataszteri adatokat rendelkezésükre bocsátották. Az elemzések az „Egészségügyi Ellátórendszer Szakmai Módszertani Fejlesztése" c. EFOP-1.8.0-VEKOP-17-2017-00001 C/II projekt keretében készültek. 


\section{HIVATKOZÁSOK}

${ }^{1}$ Pawankar R. Allergic diseases and asthma: a global public health concern and a call to action. World Allergy Organization J, 2014;7(12):1-4. https://waojournal.biomedcentral.com/articles/10.1186/1939-4551-7-12

${ }^{2}$ Csépe Z, Magyar D, Mányoki G, Bobvos J, Elekes P, Páldy A. A polleninformációs szolgáltatás fejlődése Magyarországon (Recent developments in pollen information in Hungary). Egészségtudomány, 2013;57(4):24-36.

http://egeszsegtudomany.higienikus.hu/cikk/2013-4/2013-4.pdf\#page=25

${ }^{3}$ Udvardy O, Mányoki G, Józsa E, Vadassy R, Páldy A, Magyar D. A parlagfű polleninformáció szolgáltatás eszközei. AMEGA 2015;22(6):11-15. http://www.ameganet.hu/wp-content/uploads/2014/08/Parlagfu_polleninformacio.pdf ${ }^{4}$ Hirst JM. An automatic volumetric spore trap. Ann Applied Biol, 1952;39(2):257-265. https://onlinelibrary.wiley.com/doi/abs/10.1111/j.1744-7348.1952.tb00904.x

${ }^{5}$ Galán C, Smith M, Thibaudon M, Frenguelli G, Oteros J, Gehrig R, Berger U, Clot B, Brandao R, EAS QC Working Group. Pollen monitoring: minimum requirements and reproducibility of analysis. Aerobiologia, 2014;30(4):385-395. https://link.springer.com/article/10.1007/s10453-014-9335-5

${ }^{6}$ Páldy A, Bobvos J, Fazekas B, Mányoki G, Málnási T, Magyar D. Characterisation of the pollen season by using climate specific pollen indicators. CEJOEM 2014;20(3-4):199-214.

https://www.nnk.gov.hu/cejoem/Volume20/Vol20No3-4/CE14 3-4-03.html

${ }_{7}$ Faegri K, Kaland PE, Krzywinski K. Textbook of pollen analysis (Ed. 4). John Wiley \& Sons, Chichester. 1989 https://onlinelibrary.wiley.com/doi/abs/10.1002/jqs.3390050310

${ }^{8}$ Cariñanos P, Sánchez-Mesa JA, Prieto-Baena JC, Lopez A, Guerra F, Moreno C, Domínguez E, Galán C. Pollen allergy related to the area of residence in the city of Córdoba, south-west Spain. J Environ Monitor, 2002;4(5):734-738. https://www.ncbi.nlm.nih.gov/pubmed/12400923

${ }^{9}$ Cariñanos P, Alcázar P, Galan C, Domínguez E. Privet pollen (Ligustrum sp.) as potential cause of pollinosis in the city of Córdoba, south-west Spain. Allergy 2002;57(2):92-97. https://www.ncbi.nlm.nih.gov/pubmed/11929410

${ }^{10}$ Mányoki G, Angyal Z, Gerdelics A, Magyar D. Budapest IX. kerületének biológiai levegőminősége a nyári allergén gyomok pollenkoncentráció vizsgálata alapján. Egészségtudomány, 2013;57(4):98.

https://www.antsz.hu/data/cms50251/Egeszsegtudomany 3013 LVII 4.pdf

${ }^{11}$ Sőrés E. A Normafa Parkerdőben és Budapest egyéb helyszínein mért pollenkoncentrációk vizsgálata a 2015. évi nyári pollenszezonban. PTE - MIK Környezetmérnöki Tanszék, diplomamunka. 2016

${ }^{12}$ Werchan B, Werchan M, Mücke HG, Gauger U, Simoleit A, Zuberbier T, Bergmann KC. Spatial distribution of allergenic pollen through a large metropolitan area. Environ Monitor Assessment, 2017;189(4):169.

https://www.ncbi.nlm.nih.gov/pubmed/28316024

${ }^{13}$ Fehér Z.: Aeropalinológiai Monitorozás Budapesten, az eredmények alkalmazása az aerobiológiában és az ökológiában, kézirat, doktori értekezés, Gödöllői Agrártudományi Egyetem, Növényökológia - Ökofiziológia doktori program, 1998

${ }^{14}$ Cariñanos P, Casares-Porcela M, Quesada-Rubio J-M (2014) Estimating the allergenic potential of urban green spaces: A case-study in Granada, Spain. Landsc Urban Plan, 123, 134-144.

https://www.uco.es/rea/publicaciones/andalucia/granada/Paloma Estimating 14.pdf

${ }^{15}$ Cariñanos P, Adinolfi C, Díaz de la Guardia C. Characterization of Allergen Emission Sources in Urban Areas. J Environ Quality, 2016;45(1):244-252. https://www.ncbi.nlm.nih.gov/pubmed/26828180

${ }^{16}$ Ćwik A, Kasprzyk I, Wójcik T, Borycka K, Cariñanos P. Attractiveness of urban parks for visitors versus their potential allergenic hazard: A case study in Rzeszów, Poland. Urban For Urban Green, 2018;35:221-229. https://www.sciencedirect.com/science/article/pii/S1618866718301171

${ }^{17}$ Kasprzyk I, Wójcik T, Cariñanos P, Borycka K, Ćwik A Evaluation of the allergenicity of various types of urban parks in a warm temperate climate zone. Aerobiologia, 2019;35(1):57-71.

https://link.springer.com/article/10.1007/s10453-018-9537-3

${ }_{18}$ Oja P, Vuori I, Paronen O. Daily walking and cycling to work: their utility as health-enhancing physical activity. Patient Educ Couns, 1998;33:S87-S94. https://www.ncbi.nlm.nih.gov/pubmed/10889750

${ }^{19}$ Ege C, Krag T. Cycling will improve environment and health. The Danish ecological Council, Copenhagen, 2010 http://www.cycle-helmets.com/denmark.pdf

${ }^{20}$ Buccolieri R, Gromke C, Di Sabatino S, Ruck B Aerodynamic effects of trees on pollutant concentration in street canyons. Sci Total Environ, 2009;407(19):5247-5256.

https://www.sciencedirect.com/science/article/pii/S0048969709005944 
${ }^{21}$ Farrell WJ, Weichenthal S, Goldberg M, Hatzopoulou M Evaluating air pollution exposures across cycling infrastructure types: Implications for facility design. J Transport Land Use, 2015;8(3):131-149.

https://www.jtlu.org/index.php/jtlu/article/view/702

${ }^{22}$ Inturri G, Ignaccolo M. The role of transport in mitigation and adaptation to Climate change impacts in urban areas. In Resilient Cities. Ed. Zimmermann O, Springer, Dordrecht. 465-478., 2011. https://www.researchgate.net/publication/251179698 The Role of Transport in Mitigation and Adaptation to Climate Change Impacts in Urban Areas

${ }^{23}$ Stefansdottir H. A theoretical perspective on how bicycle commuters might experience aesthetic features of urban space. J Urban Design, 2014;19(4):496-510. https://www.tandfonline.com/doi/abs/10.1080/13574809.2014.923746

${ }^{24}$ Vaskövi É, Beregszászi T, Endrődy M, Srauf Z A fővárosi kerékpárutak levegőkörnyezetének jellemzése: esettanulmány Budapesten. Egészségtudomány 2012;56(1):96-107. http://egeszsegtudomany.higienikus.hu/cikk/2012-1/2012-1.pdf

${ }^{25}$ Péter B, Beregszászi T, Hangyáné Szalkai M, Bobvos J, Páldy A. Kerékpározás és légszennyezés Budapesten -egy próbatanulmányeredményei. Egészségtudomány 2017;61(4):65 http://egeszsegtudomany.higienikus.hu/cikk/2017-4/2017$\underline{4 . p d f}$

${ }^{26}$ http://www.cyclingchallenge.eu/gps-data-collection?teamid=5719e36988c5374c7234d05f Elérve: 2018. 06. 22.

${ }^{27}$ Feliziani V. Pollini di interesse allergologico. Masson, Milano, 1986. https://link.springer.com/content/pdf/10.1007\%2FBF02450008.pdf

${ }^{28}$ Künkele U, Lecheler J. Ratgeber Pollenallergie für Patienten und Arzte, Quintessenz, München, 1992.

29 Járainé Komlódi M, Medzihradszky Z. Budapesti Pollenallergia Kalauz. Magyar Természettudományi Múzeum, Budapest, 1994.

30 Jaeger S. The European Aeroallergen Network EAN, in Second European Symposium on Aerobiology (Vienna, Austria 5-9 September 2000), Abstracts. Eds. Jaeger S, Berger U, Vienna, 98. 2000.

${ }^{31}$ Ogren TL. Allergy-Free Gardening - The Revolutionary Guide to Healthy Landscaping, Ten Speed Press, Berkeley, Toronto, 2000 https://escholarship.org/uc/item/4h3369xt

32 Hruska K. Assessment of urban allergophytes using an allergen index, Aerobiologia, 2003;19:107-111. https://link.springer.com/article/10.1023/A:1024450601697

${ }_{33}$ Nicoleta I. Aerobiological monitoring of allergenic flora in Timisoara. Lucrări ştiinţifice, Seria Horticultură, 2008;51:131-136. https://www.researchgate.net/publication/235968029 AEROBIOLOGICAL MONITORING OF ALLERGENIC FLORA IN TIMISOARA

${ }^{34}$ Cariñanos $P$, Casares-Porcel M. Urban green zones and related pollen allergy: A review. Some guidelines for designing spaces with low allergy impact. Landscape and Urban Planning, 2011;101(3): 205-214.

https://www.sciencedirect.com/science/article/pii/S016920461100137X

35 Mari A, Rasi C, Palazzo P, Scala E. Allergen databases: current status and perspectives. Curr Allergy Asthma Rep, 2009;9(5):376-383. https://link.springer.com/article/10.1007/s11882-009-0055-9

${ }^{36}$ Smith M, Cecchi L, Skjøth CA, Karrer G, Šikoparija B. Common ragweed: A threat to environmental health in Europe. Environ Int, 2013;61:115-126. https://www.sciencedirect.com/science/article/pii/s0160412013001682

${ }^{37}$ De Weger LA, Bergmann KC, Rantio-Lehtimäki A, Dahl Å, Buters J, Déchamp C, Belmonte J, Thibaudon M, Cecchi L, Besancenot J-P, Galán C, Waisel Y. Impact of pollen. In: Allergenic Pollen-A review of the production, release, distribution and health impacts. Eds. Sofiev M, Bergmann KC, Springer, Dordrecht. 2013;161-215.

https://www.springer.com/gp/book/9789400748804

${ }^{38}$ www.pollenlibrary.com Elérve: 2019. 05. 29.

${ }_{39}$ Cariñanos P, Casares-Porcel M, Díaz de la Guardia C, Aira MJ, Belmonte J, Boi M, Elvira-Rendueles B, De Linares C, Fernández-Rodriguez S, Maya-Manzano JM, Pérez-Badía R, Rodriguez-de la Cruz D, Rodríguez-Rajo FJ, Rojo-Úbeda J, Romero-Zarco C, Sánchez-Reyes E, Sánchez-Sánchez J, Tormo-Molina R, Ana M, Vega Maray. Assessing allergenicity in urban parks: a nature-based solution to reduce the impact on public health. Environ Res, 2017;155:219-227.

https://www.sciencedirect.com/science/article/pii/S0013935117302967

40 Blumenthal MN. Sports-Aggravated Allergies. Phy Sportsmed, 1990;18(12):52-66. https://www.ncbi.nlm.nih.gov/pubmed/27438276

${ }^{41}$ Behrendt H, Becker WM, Friedrichs KH, Darsow U, Tomingas R. Interaction between aeroallergens and airborne particulate matter. Int Arch Allergy Immunol, 1992;99(2-4):425-428. https://www.karger.com/Article/Abstract/236303 ${ }^{42}$ Behrendt H, Becker WM, Fritzsche C, Sliwa-Tomczok W, Tomczok J, Friedrichs KH, Ring J. Air pollution and allergy: experimental studies on modulation of allergen release from pollen by air pollutants. Int Arch Allergy Immunol, 1997;113(1-3):69-74. https://www.ncbi.nlm.nih.gov/pubmed/9130487

${ }^{43}$ Knox RB, Suphioglu C, Taylor P. Major grass pollen allergen Lol p1 binds to diesel exhaust particles: implications for asthma and air pollution. Clin Exp Allergy, 1997;27:246-251. https://www.ncbi.nlm.nih.gov/pubmed/9088650 
${ }^{44}$ Krämer U, Koch T, Ranft U, Ring J, Behrendt H. Traffic-related air pollution is associated with atopy in children living in urban areas. Epidemiology, 2000;11, 64-70. https://www.ncbi.nlm.nih.gov/pubmed/10615846

${ }^{45}$ Kondo Y, Ipsen H, Lowenstein H, Karpas A, Hsieh LS. Comparison of concentrations of Cry j 1 and Cry j 2 in diploid and triploid Japanese Cedar (Cryptomeria japonica) pollen extracts. Allergy, 1997;52(4):455-459.

https://www.ncbi.nlm.nih.gov/pubmed/9188931

${ }^{46}$ de Dios Alché J, Zafra A, Jiménez-López JC, Morales S, Castro AJ, Florido F, Rodríguez-García MI. Pollen Allergenicity is Highly Dependent on the Plant Genetic Background: The "Variety" /Cultivar" Issues. In: Current insights in pollen allergens. Ed. Jimenez-Lopez JC, IntechOpen, London. 1-25, 2012 http://cdn.intechopen.com/pdfs/40986/InTech-Pollen_allergenicity_is_highly_dependent_on_the_plant_genetic_background_the_variety_cultivar_issues.pdf

${ }_{47}$ Bergmann K, Zuberbier T, Augustin J, Mücke H, Straff W. Climate change and pollen allergy: cities and municipalities should take people suffering from pollen allergy into account when planting in public spaces. Allergo J, 2012;21(2):103107. http://www.pollenstiftung.de/uploads/media/Article Allergo Journal 2 2012.pdf

${ }^{48}$ Magyar D, Mányoki G. Állásfoglalás a hazánkban előforduló, allergén pollent kibocsátó növényekről. Az Országos Közegészségügyi Központ kiadványa, Budapest, 2016 www.oki.antsz.hu/files/dokumentumtar/Allergen fafajok listaja.pdf Elérve: 2019.04.01.

${ }^{49}$ Szabó K (szerk.) Közterületi sorfák jegyzéke. Magyar Díszkertészek Szövetsége, Budapest, 2018

https://www.diszkerteszek.hu/ma files/2019 kiadvany 2018.pdf 